\title{
Halal and Non-Halal Gelatine as a Potential Animal By-Products in Food Systems: Prospects and Challenges for Muslim Community
}

\author{
Zamzahaila Mohd Zin ${ }^{* 1}$, Norizah Mhd Sarbon ${ }^{2}$, Mohamad Khairi Zainol ${ }^{3}$, Siti \\ Nur'Afifah Jaafar ${ }^{4}$, Madihah Mohamad Shukri ${ }^{5}$ and Asyraf Hj Ab. Rahman ${ }^{6}$ \\ ${ }^{1,2,3,4}$ Faculty of Fisheries and Food Science, Universiti Malaysia Terengganu, 21030 Kuala Nerus, Terengganu, \\ Malaysia \\ ${ }^{5}$ Faculty of Business, Economics and Social Development, Universiti Malaysia Terengganu, 21030 Kuala Nerus, \\ Terengganu, Malaysia \\ ${ }^{6}$ Centre for Fundamental and Continuing Education, Universiti Malaysia Terengganu, 21030 Kuala Nerus, Terengganu, \\ Malaysia \\ *Corresponding author. Email: zamzahaila@umt.edu.my
}

\begin{abstract}
Halal is the concept of granting any entity or practise that is deemed to be lawful under Islamic law to be used or consumed. These terms are commonly used with respect to food products, meat products, cosmetics, personal care products, pharmaceuticals, food ingredients, and food contact materials. The increase of Muslim population in this world also requires more awareness and concern among Muslim consumers on halal products. The unique gelling, stabilizing, healing, ointment, capsule and coating properties of gelatine made are among the most widely used biodegradable compounds in commercial consumer goods. Since pigskin (porcine) is the main source of gelatine on the international market, it is often controversial for religious believers such as Muslims and Jews. The need for gelatine obtained from Halal sources, such as alternative Halal gelatine derived from poultry or animal by-products of meat processing (such as skins, heads, feathers, viscera, bones and legs), has therefore become essential, as well as other marine sources in which a possible alternative to porcine gelatine could be found. Halal has been a long-disputed issue due to the reason of its complexity consequently of swift advancement in innovation, technology and porcinederived gelatine adulteration, etc. Other challenges include sustainability of alternative gelatine, such as sources, waste or by-product management practises, consumer religiosity, halal awareness, halal certification, government policy, food suppliers, marketers and the purchasing of halal products among consumers. This paper will therefore highlight the Halal and Non-Halal problem of gelatine, which plays a critical role in modern food processing and pharmaceuticals, as well as looking for potential opportunities and challenges for the Muslim community.
\end{abstract}

Keywords: animal by-products, food ingredients, gelatine, halal, porcine,

\section{INTRODUCTION}

Halal is a concept that assigns any entity or activity allowed to be used or engaged in accordance with Islamic law. These terms are commonly used with respect to food products, meat products, cosmetics, personal care products, pharmaceuticals, food ingredients, and food contact materials [1].
Since the production of a food product comprising a particular process, starting from the selection, preparation of materials, manufacturing, production, storage, transportation, distribution until the product has been presented to the consumer, then the "halal" should cover the whole network starting from its source [2]. There will 
be $31.1 \%$ of Muslims world population projected in 2060 [3]. Therefore, the provision of consumption needs of Muslims as well will continue to increase. The concern of consumers regarding halal food is not only to satisfy the need for religious doctrine, but also to ensure food safety. Alfarisi (2017) [4] stated that halal food is not only concerned with religious issues, but also with lifestyle and quality assurance in the sense of business and trade. This shows that the halal market continues to expand supported by increased awareness of its importance, quality and safety of the product. In addition, this suggests a change in customer perception towards the concept of halal.

The Economic Council (2011) reported that the halal market is growing fast and an increase of about $25 \%$ per year [5]. It is also projected that the halal market will cross US $\$ 80$ billion a year worldwide and the growth rate predicted by the halal food industry is 7 percent annually [6]. The growth of halal industry is not only found in Muslim countries. The increased of Muslim populations in non-Muslim countries also contributes to the high number of halal industry needs, especially halal food products for Muslims themselves. Halal becomes the lifestyle of Muslim consumers in the world. As the Muslim population increasing, the awareness on consuming halal food also improving. Recently, food production has been prepared based on the advancement of modern science and technology. There are several ingredient sources which have been used in the production of food products. These ingredients are either permissible (halal) or prohibited (haram). With regard to the rise in demand for halal food, many scholars and scientists raise the issue of gelatine derived from pig skin is used in almost every processed food product [7]. Nevertheless, as $95 \%$ of the gelatine on the market is made from animals forbidden for Muslim use, it has become a sensitive issue. Though the use of food products adulterated with porcine-derived gelatine also create concerns in the mind of Muslim communities. In contrast to that, pork derived gelatine can be replaced by using gelatine derived from halal sources such as fish, cow, chicken and turkey derived gelatine. The need of this review is to shed light on the issue of Halal and non-halal gelatine-based products consumption, government policy, consumer awareness, and other alternatives to food producers. This review might be helpful in the future regarding knowledge and significance about porcine, and its Halal alternative derived gelatine.

\section{MATERIALS AND METHOD}

This study involves review and analysis of secondary data in an attempt to examine an alternative perspective on the original question of halal and non-halal gelatine in food systems. In order to collect relevant information and data, a systematic literature search (magazines, books, journals, newspapers, and conference papers) was conducted. The materials not only limited to the English language but also covers Malay language materials. All the data are discussed and presented using descriptive approaches based on selected themes related to the study objectives.

\section{RESULTS AND DISCUSSION}

\subsection{Halal and Haram from Islamic Perspective}

The term "halal" refers to the area of living arrangements of Muslims guided by halalan tayyiban, including purity, hygiene, and healthy living, as well as halal [8]-[9]. Terms halal opposed to illegal or out of something illegal or prohibited [10]. According to Kamus Dewan (2005) [11], halal is well defined as halal law permits an act is done (in Islam), legal (not forbidden by Islam), permitted and allowed. Halal means permissible and lawful, haram means not allowed and illegitimate, while syubhat means dubious, still in question and should be avoided [5]. Halal food products alone are not sufficient but must include aspects of "good" (tayyib) that are clean, safe, and quality.

Prophet Mohammad (P.B.U.H) said: "Verily, the lawful (Halal) is clear and the unlawful (Haram) is clear, and between the two of them are doubtful matters about which many people do not know. Thus, he who avoids doubtful matters clears himself in regard to his religion and his honor, and he who falls into doubtful matters will fall into the unlawful as the shepherd who pastures near a sanctuary, all but grazing therein. Verily, every king has a sanctum and the sanctum of Allah is his prohibitions. Verily, in the body is a piece of flesh which, if sound, the entire body is sound, and if corrupt, the entire body is corrupt. Truly, it is the heart." [Sahih Bukhari 52, Sahih Muslim 1599]

According to al-Qaradawi (1994), something that is required, that no binding ban and allowed someone to do so by legislation. Al-Ghazali (1998) and Al Qaradawi (2002) also clarifies the meaning of halal, which covers all major sources of human food either from animals, plants, natural materials, chemicals and microorganisms contained between lawful and unlawful law. Consumption of pork and products made from pork is strictly forbidden in Islam. Suggestions related to halal and haram food poured in the verses of the Qur'an (Al-Baqarah: 172-173; Al-Maidah: 3; Al-Maidah: 88).

"O you who have believed, eat from the good things which We have provided for you and be grateful to Allah if it is [indeed] Him that you worship. He has only forbidden to you dead animals, blood, the flesh of swine, and that which has been dedicated to other than Allah. But whoever is forced [by necessity], neither desiring [it] nor transgressing [its limit], there is no sin upon him. Indeed, Allah is Forgiving and Merciful”. [Surah Al-Baqarah:172-173]

"Prohibited to you are dead animals, blood, the flesh of swine, and that which has been dedicated to other than Allah, and [those animals] killed by strangling or by a violent blow or by a head-long fall or by the goring of horns, and those from which a wild animal has eaten, except what you [are able to] slaughter [before its death], and those which are sacrificed on stone altars, and [prohibited is] that you seek decision through 
divining arrows. That is grave disobedience. This day those who disbelieve have despaired of [defeating] your religion; so fear them not, but fear Me. This day I have perfected for you your religion and completed My favor upon you and have approved for you Islam as religion. But whoever is forced by severe hunger with no inclination to sinthen indeed, Allah is Forgiving and Merciful". [Surah Al-Maidah:3]

"And eat of the lawful and good (things) that Allah has given you and be careful of (your duty to) Allah, in whom you believe". [Surah AlMaidah:88]

In addition, the Qur'an also explains that a Muslim is recommended to consume halal and good food (AlBaqarah:168; Al-Mu'minun:51). Therefore, the halalness of food and drink is a major consideration for a Muslim.

'o men! eat the lawful and good things out of what

is in the earth, and do not follow the footsteps of the shaitan; surely he is your open enemy" (AlBaqarah: 168)

"o messengers! eat of the good things and do good; surely $i$ know what you do" Al Mu'minun: 51)

There are also doubtful things and in Islamic law. This source of mashbooh is dubious and questionable in Islamic law. For instance, food that has been added with substance from doubtful based ingredients into halal food products. This is mentioned in the sunnah of the Prophet Muhammad (s.a.w.) where it is stated that:

"Both doubtful things are evident but in between there are doubtful (mashbooh) things and most of the people having no knowledge about them. So whoever saves himself from these doubtful things, he saves his religion and his honor, but he who falls into doubtful matters falls into that which is unlawful, like the shepherd who pastures around a sanctuary, all but grazing therein. Truly every kind has a sanctuary, and truly Allah (s.w.t.) sanctuary is His prohibition." (Al-Bukhari, 1979)[12]

\subsection{Halal and Non-Halal Gelatine}

Gelatine is an insoluble fibrous protein with high molecular weight that exists in vertebrates and is the primary constituent of connective tissues and bones. According to the De Pietro (2017) [13], gelatin is made by boiling animal bones, cartilage, and skin to extract the collagen. There are several varieties of gelatine, the composition of which depends on the source of collagen and the hydrolytic treatment used. Raw materials for the production of commercial gelatines are processed in low and high $\mathrm{pH}$ environments [14]. Most gelatine is one of two types: Type A gelatine is exclusively made from pork skins; the raw material is treated for $18-30 \mathrm{~h}$ in an acidic environment at $\mathrm{pH}$ 1.5-3.0 and is hence Haram for
Muslims to use. For Type B gelatine, the raw material is treated in an alkaline medium at $\mathrm{pH} 12.0$ for several weeks to months. It is made either from cattle and calf skins or from demineralized cattle bones, poultry skins or other permitted animals (slaughtered according to Islamic rites, as explained in Islamic Law Slaughtering). Its halal status depends on the nature of raw materials used in its manufacture.

"Tell them (O Muhammad!): 'I do not find in what has been revealed to me anything forbidden for anyone who wants to eat unless it is carrion, outpoured blood and the flesh of swine, all of which is unclean; or that which is profane having been slaughtered in a name other than that of Allah. But whosoever is constrained to it by necessity - neither desiring to disobey nor exceeding the limit of necessity - your Lord is surely All Forgiving, All-Compassionate”. (Al An'Am:145)

Around 80 percent of the gelatin in Europe is made from pigskin. Moreover, most of the food manufacturers use porcine-derived gelatine rather than its alternatives [15]. Gelatine Manufacturers of Europe (GME) reports the annual world production of gelatine is nearly 326,000 tons, with source from pig skin derived gelatine is the most abundant (46\%) output, followed by bovine hides (29.4\%), bones $(23.1 \%)$ and other sources $(1.5 \%)$ [16]. Porcine skin requires short time for treatment with acid prior to extraction while for bovine it is subjected to lengthy treatment with alkaline. The raw materials for this mammal are also abundant and the price is lower compared to bovine. There are differences between functional properties of porcine and bovine gelatine based on their amino acid composition, polypeptides pattern, bloom strength, turbidity and foaming properties [17]. Alternative gelatine maybe produced from the skins of cold and warm water fish species, and minor quantities come from avian sources [18]. There are no plant sources of gelatine, and there is no chemical relationship between gelatine and materials referred to as vegetable gelatine (i.e. seaweed extracts) [18].

\subsection{Commercial Uses of Gelatine}

Gelatin is the most commonly used biodegradable compound in commercial food production, pharmaceutical and photographic industries because of its special gelling, stabilizing, curing, ointment, capsule, coating properties [19]-[20] as well as its special rheological properties and its melt-in-the-mouth texture [21]. Gelatine is primarily used in the food industry as an emulsifier, foaming agent, colloid stabilizer, biodegradable film-forming material, microencapsulating agent [22] and commonly used as property to form thermoreversible gels [23]. At a few percent gelatine in water, gelatine's gel-melting temperature is below body temperature $\left(<35^{\circ} \mathrm{C}\right)$, which can provide gelatine products with a unique 'melt-in-the- 
mouth' quality. Gelatine will be soft and turn into liquid after being heated. In addition, it's also able to melt below human body temperature that allows gelatine to melt and release flavour, which is a desirable sensorial property for some food products [24]. Another important characteristic of gelatine, its gel has higher strength than most of the other common gelling agents, which are usually carbohydrates and obtained from vegetable sources [25].

Gelatine is a traditional functional protein with watersoluble properties which, under some conditions, has the ability to form transparent gels. The clear and transparent structure of gelatine accounts for its significance, especially in the food and pharmaceutical industries [19]. Moreover, during cold storage, gelatin also prevents lactose sugar recrystallization. (Jamilah and Harvinder, 2002) [26]. It has been reported that, annually, tons of gelatine have been used in many food products, including jellies, candies, desert, meat ice cream, confectionery, cookies, and bakery products. It is also used in non-food products, including medical products, and in veterinary applications. While in the pharmaceutical industry, the making of hard and soft capsule shells, tablets, granulation and syrups, all requires gelatine because it serves as a natural coating material and is also highly digestible.

Many people today are concerned about their health and are taking supplements such as Vitamin E or fish oil, and the list goes on to boost immunity of their body [9]. The soft gel capsules were also used because they look appealing and have a smooth finish, making it easier to swallow. According to Capsugel, a major manufacturer of capsules, most soft gel capsules are made from gelatine [27] wherein the main sources are from animal skin especially pigskin and lard [28]. As a result, gelatine capsules are not ideal for use by people of strong religious value who do not consume certain animals for certain religious reasons [29].

"Allah has forbidden you only carrion, and blood, and the flesh of swine; also any animal over which the name of any other than Allah has been pronounced. But whoever eats of them under compelling necessity - neither desiring it nor exceeding the limit of absolute necessity - surely for such action Allah is Much Forgiving, Most Merciful". (An-Nahl: 115)

Gelatine also plays an important role in the manufacturing of energy drinks for athletes in the sports industry and is a vital component of energy drinks. (Phillips and Williams, 2011)[30]. In photography, it was first used in 1871 when the sensitising agent was coated on a glass plate in gelatine. The use of gelatine in the cosmetics industry is of considerable significance as it is widely used in shampoo, lipstick, conditioner, cream and fingernail formulations. The increase in the production of biodegradable polymers such as gelatin attracts worldwide attention, one of the reasons why producers consider it an attractive choice is due to its antioxidant properties [31]-[32].

\subsection{Prospect in Halal Gelatine Industries}

\subsubsection{Alternative gelatine produced from other halal sources}

Global demand for the gelatine industry is growing, particularly in the food and pharmaceutical industries, on a daily basis. Primary gelatine production is produced from mammalian (porcine and bovine). The use of bovine carrying prion proteins has been linked to bovine spongiform encephalopathy (BSE) (mad cow disease) causing immune response that led to fatal neurodegenerative disease (spongy degeneration of the brain and spinal cord) in cattle [33]. Also, bovine and porcine gelatines are risky to gelatine-allergic patients [34]. Due to the emergence of mad cow disease and the unacceptability of bovine and porcine gelatine by the Muslim, Jewish and Hindu communities, there is a growing interest in the production of alternative gelatine from fish waste [35]. It is reported in a Saheeh [authentic] Hadith that fish is lawful to eat; the Prophet said:

"There are two dead animals that are lawful for us

(to eat): they are fish and locusts..." [Ahmad and

Ibn Maajah]

Compared to porcine-derived gelatine alternatives, the market share of fish gelatine is still poor compared to bovine and porcine gelatine [24]. A number of studies have been published on the production of gelatine alternatives to mammalian gelatine from fish sources, including fish skin [36]-[37] and fish scales [38]. A large number of available scientific studies have confirmed that aquatic-derived gelatin has stronger film-forming properties than mammals [39]. In addition, fish gelatine with a low melting point has been documented to have strong release properties of sensory food attributes [40]. Fish gelatine has biologically active peptides, and such peptides have the ability to act as antioxidants [41]-[42]. In addition, gelatine extracted from Pacific cod skin demonstrates a strong inhibitory effect of angiotensin-Iconverting enzyme (ACE), an important enzyme in the regulation of hypertension and type 2 diabetes [43]. Furthermore, Jridi et al. (2013) [44] proposed that it be used to minimise blood pressure and cardiovascular disease (CVD) in functional food preparation.

Compared to mammalian gelatin, gelatin from cold water fish species has sub-optimal physical properties, which restrict demand for it [45]. Meanwhile warm water fish gelatines have physical properties comparable to those of mammalian gelatines, but their modest production and low extraction yields result in less efficient pricing compared to mammalian gelatines [26]. According to Hall (2015) [46], high cost of transport and the low concentration of collagen in fish skins makes it considerably more expensive than gelatine that is produced traditionally. Other problems and health risks related to fish gelatine include allergic reactions. The provision of gelatine derived from halal sources has therefore become an important issue, as gelatine derived from aquatic sources 
may be more relevant in the halal or kosher market than mammalian and porcine gelatine.

New potential sources of halal gelatine, such as poultry skin, legs and bones, are therefore gaining attention as alternatives to mammalian-derived gelatine replacement [47]. Gelatine from poultry has been receiving some attention since feet and skin rich in collagenous protein 48]. According to Hall (2015) [46], chicken skin gelatine which the chicken is slaughtered in the Islamic way can be another alternative for mammalian gelatine. Sarbon et al. (2013) [49] also reported that chicken gelatine showed higher gelling temperatures compared to bovine gelatine. Gelatine derived from the poultry waste also exhibits metal chelating and radical scavenging properties and can be considered as a Halal alternative of porcine gelatine [50]. Some other valuable peptides are also reported for its beneficial activity by many researchers confirmed the broad and wide range of available and functional peptides from porcine alternative sources [51]. Thereby, according to Jridi et al. (2013) [44] all gelatines in all probability contained peptides which are electron or hydrogen donors that convert the free radical to the more stable product by reacting with them and dismiss the radical chain reaction. Furthermore, since most of the slaughterhouse in Malaysia is Halal-certified, the production of gelatine from chicken skin can be beneficial for the food industries. Therefore, the study of gelatine from chicken, such as skin is interesting as sources of collagen to extract gelatine. However, fish gelatine (advantage of having odourless properties) has the edge over poultry gelatine due to the complication in managing poultry wastes [16].

\subsubsection{From waste to wealth}

Due to its price competitive aspect, nutritional value and because it is free from social constraints in the eating point of view, there is a huge increase in global demand for various poultry products. Huge quantities of waste and byproducts are generated due to large numbers of poultry being slaughtered for the production of a variety of poultry meat and meat products. Slaughtering and processing of poultry birds give only one third as meat portion while the rest as poultry wastes and by-products, which need to be effectively processed and utilized. Poultry by-products include offal, bone, blood, viscera, head, feet and feathers, mechanically deboned poultry. The waste not only causes pollution but also it emits defensive odour [52].

Non-utilization of animal by-products in a proper way may create major aesthetic and catastrophic health problems. Poultry waste is one of the major pollutants if not properly disposed of. These cause environmental pollution and health hazards, attract flies and harbour various pathogenic microbes. The waste generated in industries of meat products are frequently very large and represent a serious problem due to the high content of organic matter, and these wastes can serve as sources of microorganisms' proliferation. Thus, according to Pelizer et al. (2007) [53] the environmental problems are worsened by inadequate treatment of industrial solid waste. In this way, it is necessary to minimize these wastes, even before they reach the grease and rendering plants. Underutilization of by-products not only lead to loss of potential revenues but also lead to the increasing cost of their disposal.

The utilization of animal by-products is often ignored; however, these items contribute a significant value to the livestock and meat industries. Poultry by-products can act as a source of energy, livestock feed, fertilizer, liming components for soil, collagen, gelatine and calcium. After suitable processing, poultry by-products can be converted into feather meal, hydrolysed feather meal and poultry byproduct meal. The utilization of waste skin and bone from poultry for production of value added by-products has attracted substantial attention. Instead of being waste that can cause pollution to the environment, poultry meat industry wastes have a potential for recycling raw materials into products of higher value, can be used for production of gelatine. This serves as a good practice of post-harvest management of waste utilisation. Therefore, more work is required in the sector of waste management and adapting the state of art industrial technology to produce Halal gelatine inside the country. In addition to that, Islamic countries can produce a handsome amount of Halal gelatine with proper waste management practices and industrial technology.

\subsubsection{Halal certification}

Halal certification involves not only the products to be consumed directly by consumers. However, it involves all aspects of the production chain such as equipment used and other materials added to the product. As Muslim countries have increased imports of food products, there has been growing awareness of the problem gelatine presents to Muslim consumers. Increase in Halal awareness among Muslims has called for a great need of food-source authentications. Gelatine and gelatine-based products are currently classified as doubtful/mashbooh because haram (porcine) gelatine is the most abundant. Traceability of gelatine source has been a great task in Halal field. Other reasons for gelatine source authentication include: (i) protection of consumers from food frauds due to false labeling and avoid unfair market competition [54] and (ii) health issues. According to Food Regulations 1985 state on law no 153 which is under edible gelatine. No label on any package containing gelatine shall claim that the food is edible gelatine unless the common name of the animal from which the edible gelatine is obtained is stated on such label [ $\mathrm{R} 153$ (3)]. Besides that, where edible gelatine has been added to any food, there shall be written in the label on a package containing such food, in not less than 10-point lettering, the words "contains edible gelatine from (state the common name of the animal from which the edible gelatine is obtained)" [R 153 (4)]. Which means that any food that contains, source or claim as gelatine should clearly state the type of gelatine and source of gelatine.

The presence of halal logos on food products is a special consideration for Muslims. However, this halal logo does 
not just represent that the product is lawful for Muslims. In addition to ensuring that a product is halal. It should also guarantee a product's security, efficiency, and cleanliness. This is also to ensure that this product is not only for Muslims because of its halalness, but also for anyone who will feel safe to consume the product. So, consumers will have an interest in buying these halal food products. Halal labelling on the product becomes a sign that the product has been certified halal which is tightly tested. Halal certification is a guarantee of security for people Muslims to be able to consume a product [6]. Nevertheless, to inspire Malaysian as world Halal Hub, the Halal logo should in line with hazard analysis and critical control point (HACCP) certification, high quality standards of ISO9001 certified, attention to environment issue of ISO14001 certified; and infrastructure and technologies support for Halal authentication analysis. This will provide scientific evidence to substantiate any claims regarding the presence or absence of the non-Halal ingredients and/or additives. Those criteria implied that the Halal logo has high quality of hygienic, safety and Halal assurance of products for consumption. This will attract the non-Muslim consumers towards the Halal concept and earn a great opportunity to lucrative Halal business in local and international markets. The growing concern among the Muslims about Halal food [55] as well as the increasing trend in attitude and intention to purchase Halal food products by non-Muslims [56] escalated the demand that leads to the growth of this industry.

\subsubsection{Halal and Non-Halal gelatin identification}

Food security extends not only to safety and health issues but religious considerations as well. Not only is Halal limited to religious matters, but it can also be extended to other applications for life as it offers a number of advantages. Furthermore, halal has long been a prevailing issue in the field of food-related safety research. Notwithstanding, there remains a general paucity of research in identifying the specific form of halal and nonhalal ingredients in the products, such as the animal fat, gelatine, blood plasma, transglutaminase enzymes and so on. At present, the existing studies on identification of animal gelatine emphasize on the demand side, but studies on the technical side are scarce and largely inconclusive. In the global realm, the need of tools to ensure that food is consumed safely and is a guarantee that it is free from nonhalal materials requires a technology and non-halal detection application. Proper methods for the identification of Halal and non-Halal gelatine due to the momentous demand of Halal products today [9].

Various methods of detection of non-halal materials have developed rapidly such as FTIR spectrophotometry [57], differential scanning calorimetry [8], liquid chromatography [58], immunoelectrophoresis [59], polymerase chain reaction (PCR)-RFLP DNA based methods [60], real-time PCR [61] and immunosorbent assay (ELISA) [62]. Some of these methods are too laborious and time-consuming, consequently, an analytical technique offering rapid and reliable methods must be used. One of the promising methods suitable for routine analysis is polymerase chain reaction (PCR) [63]. The other promising technique is the PCR- southern hybridization analysis. This technique is a combination of PCR and southern hybridization analysis that were reported by Sahilah et al. (2012b) [64] and (2015) [65] in Halal market surveillance of gelatin capsules in pharmaceuticals market in Malaysia. The most reliable and robust method to overcome the disputability of Halal food products must be developed. There are many opportunities for researchers to develop porcine detection kits with a lower cost, reliable and sensitive protocol for routine analysis, have been validated by ISO 17025 accredited lab, fast and accurate, user friendly, sensitive to various types of sample scopes, and most importantly technical consultation is provided.

\subsection{Challenges for Muslim Community}

\subsubsection{Consumer awareness regarding gelatine}

Halal gelatine production in the world is projected to be less than 1\% (Halalgel®) and has become a challenge toward Muslims globally. Porcine gelatine is the most preferred than bovine for several reasons. Fulfilling the needs of Muslim consumption is different because of the demand for halal food and healthy food, even though Muslims live in a non-state Muslim. It is therefore important to increase knowledge of the use of halal foods. According to Riaz and Chaundry (2004) [66], religion, race, information, perception and others are several factors which influence consumption. Islam forbids Khamr, goats, dogs, etc. Jewish also have a law called Kosher, whereas Hinduism and Buddhists are determined not to eat cattle or be vegetarian [4]. Shaari and Arifin (2010) [67] clarify that halal awareness is the degree of information Muslim consumers need to find and consume halal products in compliance with the Sharia law. The development of halal awareness-related research over several years is rapidly growing [5];[68]-[69]. Halal food is also a power pull business in non-Muslim countries [68]. According to The Halal Journal (2008), the estimated total halal-based goods and services industry in the world is worth more than USD 1 trillion, including tourism and hospitality (restaurants and hotels complying with Sharia law) finance, beauty, and so on [5]. Yunus et al., (2013) [70] claims that a Muslim's halal consciousness has a major effect on the purchasing intention of consumers [5].

Awareness is the capacity to perceive, sense, and be aware of events and things. Knowledge was believed to be an important role in deciding the decision to select [6]. Bashir et al. (2018) [71] demonstrate that there is a major impact between perception and buying actions. The surprising part is only the aspects of behaviours that have a significant relationship with the purchasing goal, whereas the subjective norms and behavioural regulation (perceived behavioural control) have shown no significant relationship. In addition, the study conducted by Machali 
et al. (2013) [72] shows that the level of halal awareness of halal food is high enough, and that the effect of awareness of purchasing decisions is also positive and important, with religiosity as a moderating variable.

" $O$ Messengers, eat of the good things, and do good deeds; verily I am aware of what you do" (Al-

Mu'minun: 51).

The widespread knowledge, extolling the virtues of consuming clean and halal foods, and its connection to their daily religious practices reinforce this awareness. If the consumer has halal awareness, then the purchase intention becomes high and consistent to the halal product only. Therefore, the company will feel required to acquire or maintain halal certification. This has also been one of the marketing strategies for acquiring customers for the company. Halal awareness is not only seen from the point of view of consumers, but also from the point of view of the manufacturer. There are many Muslim consumer still buy food in restaurant without halal label. It also affects the manufacturer or food entrepreneurs not to register their products in order to obtain halal certification [5]. Existing food products on the market today many come from abroad. There are many foreign foodstuffs that may not exist in our country. In addition, the use of foreign terms in the composition of the material food is widely available in instant food products that much-loved the community. With current media and technology roles, consumers should have a higher awareness to know the composition of food on a product. Food ingredients become one of the decisive factors in predicting how consumers react to food products [5].

\subsubsection{Halal Authentication - potential adulteration of non-halal ingredient}

Recently, food production has been prepared based on the advancement of modern science and technology. There are many sources of ingredients which have been used in food product manufacturing. These ingredients are either permissible (halal) or prohibited (haram). There is also a discussion among the scholars associated with the procurement of raw material, processing, packaging, shipping and so on. In other words, the food chain discussion starts from farm management to consumers (from farm to fork). Since more food is available on the market, there has been concern among Muslim consumers around the world about the authenticity of halal food. This is because adulteration of haram or shubhah ingredient in food products has been widespread and difficult to identify with the naked eye.

Adulteration is a legal term for a food product which fails to meet certain standards. Adulteration usually refers to non-compliance to health or safety standards according to the Food and Drug Administration (FDA) and the U.S. Department of Agriculture (USDA). Food adulteration is the act of intentionally debasing the quality of food offered for sale either by admixture or substitution of inferior substances or by the removal of some valuable ingredient. Adulterants may be intentionally added to more expensive substances to increase visible quantities, reduce manufacturing costs and other deceptive or malicious purposes. Adulterants may also be accidentally or unknowingly introduced into the substances.

The growing number of Muslim populations uplifted the demand of Halal food. Since the boom of this concept all over the world, this Halal food industry has witnessed several food scares and food-related lawsuits. Other than adulteration of haram or shubhah ingredient, Halal logo fraud also become one of the popular cases occurred. The increase of food product in the market that uses fake Halal logo remains plentiful. As such, it is recommended that the authorities monitoring the products marketed in Malaysia and take more stern action to combat fraud in the use of non-Halal additives and giving away the Halal certification. In addition, the task of halal authentication cannot rely only on expertise from shariah alone, but also require other related technical fields such as food science and technology, chemistry and veterinary science.

\section{CONCLUSION}

Halal has been a long-disputed issue due to the reason for its complexity consequently of swift advancement in innovation and technology. The advance in food technology has progressed so much and getting more complicated. All sorts of ingredients had been used in foods which are difficult to understand by the consumer, unless they are involved directly in the related field. Global demand for the gelatine industry is increasing especially in the food and pharmaceutical industries. Pigskin is the main source of gelatine production on the international market, but it is still problematic for ethnic groups such as Muslims and Jews. New potential alternative gelatine sources such as fish, poultry skin and bone have risen to replace mammalian resources. Gelatine from skin and bone of fish and poultry are considered as by-products, so apart from gelatine extraction, it can minimize the product from industrial waste. Sustainability of alternative gelatine, such as sources, waste or byproduct management, consumer religiosity, halal awareness, halal certification, government policy, adulteration, advertisers and the purchasing of halal products among consumers are among challenges in halal food industries.

\section{REFERENCES}

[1] H. Herpandi, N. Huda and F. Adzitey, Fish bone and scale as a potential source of halal gelatin. Journal of Fisheries and Aquatic Science, 6(4) (2011) 379-389. doi:10.3923/jfas.2011.379.389

[2] A. J. Soraji, M. D. Awang and A. N. M. Yusoff, Gaps in The Legislation Halal in Malaysia: A Study of Literature. International E-Journal of Advances in Social Sciences, 3(7) (2017) 175-182. DOI: 
http://www.ocerint.org/adved16_e-proceedings/ papers/180.pdf

[3] C. Hackett, M. Stonawski and D. McClendon, The changing global religious landscape. Pew Research Center. 2017.

[4] M. S. Alfarisi, Preferensi Masyarakat terhadap Pembelian Produk Makanan Halal di Dusun Mlangi Yogyakarta. 2017

[5] D. Waskito, Pengaruh Sertifikasi Halal, Kesadaran Halal, Dan Bahan Makanann Terhadap Minat Beli Produk Makanan Halal. Studi Pada Mahasiswa Muslim Di Yogyakarta. Fakultas Ekonomi Universitas Negeri Yogyakarta, Yogyakarta 2015.

[6] Y. A. Aziz and N. V. Chok, The role of Halal awareness, Halal certification, and marketing components in determining Halal purchase intention among non-Muslims in Malaysia: A structural equation modeling approach. Journal of International Food \& Agribusiness Marketing, 25(1) (2013) 1-23.

[7] G. Boran and J. M. Regenstein, Fish gelatin. In Advances in food and nutrition research. Academic Press. 60 (2010) 119-143.

[8] J. M. N. Marikkar, O. M. Lai, H. M. Ghazali and Y. B. Che Man, Detection of lard and randomized lard as adulterants in refined-bleached-deodorized palm oil by differential scanning calorimetry. Journal of the American Oil Chemists' Society, 78(11) (2001) 11131119. DOI: $10.1007 / \mathrm{s} 11746-001-0398-5$

[9] M. A. A. Halim, M. M. Salleh, M. I. A. M. Kashim, A. A. Ahmad and N. Nordin, Halal pharmaceuticals: legal, shari'ah issues and fatwa of drug, gelatine and alcohol. International Journal of Asian Social Science, 4(12) (2014) 1176-1190.

[10]

[11] K. Dewan, Kuala Lumpur: Dewan Bahasa dan Pustaka. 2005.

[12] M. I. I. al-Bukhari, Sahih al-Bukhari. 8 vols. Istanbul: Al-Maktabah al-Islamiyyah. Trans. Muhammad Muhsin Khan. Lahore: Kazi Publications. 1979.

[12] M. I. I. al-Bukhari, Sahih al-Bukhari. 8 vols. Istanbul: Al-Maktabah al-Islamiyyah. Trans. Muhammad Muhsin Khan. Lahore: Kazi Publications. 1979.

[13] M. A. De Pietro, Eight health benefits of gelatin. Medical News Today [online]. 2019. Available from https://www.medicalnewstoday.com/articles/319124\#ta keaway
[14] R. Schrieber and H. Gareis, Gelatine handbook: theory and industrial practice. John Wiley \& Sons. 2007.

[15] K. Jayathilakan, K. Sultana, K. Radhakrishna and A. S. Bawa, Utilization of byproducts and waste materials from meat, poultry and fish processing industries: a review. Journal of food science and technology, 49(3) (2012) 278-293.

[16] GME, Gelatin Manufacturers of Europe. 2011. Available online: https://www.gelatine.org/gelatine/ safety.html

[17] R. M. R. N. Hafidz, C. M. Yaakob, I. Amin and A Noorfaizan, Chemical and functional properties of bovine and porcine skin gelatin. International Food Research Journal, 18 (2011), 813-817.

[18] A. A. Mariod and H. Fadul, Gelatin, source, extraction and industrial applications. Acta Scientiarum Polonorum Technologia Alimentaria, 12(2) (2013) 135147.

[19] K. B. Djagny, Z. Wang and S. Xu, Gelatin: a valuable protein for food and pharmaceutical industries. Critical reviews in food science and nutrition, 41(6) (2001) 481-492.

[20] T. Wang, X. K. Zhu, X. T. Xue and D. Y. Wu, Hydrogel sheets of chitosan, honey and gelatin as burn wound dressings. Carbohydrate polymers, 88(1) (2012) 75-83.

[21] I. J. Haug and K. I. Draget, Gelatin. In,"Phillips, GO, and Williams, PA (Eds.).“. Handbook of hydrocolloids, (2009) 67-86.

[22] M. C. Gómez-Guillén, B. Giménez, M. A. LópezCaballero and M. P. Montero, Functional and bioactive properties of collagen and gelatin from alternative sources: A review. Food hydrocolloids, 25(8) (2011) 1813-1827.

[23] M. E. Ali, M. A. Razzak, S. B. Abd Hamid, M. M. Rahman, M. Al Amin and N. R. Abd Rashid, Multiplex PCR assay for the detection of five meat species forbidden in Islamic foods. Food chemistry, 177 (2015) 214-224. DOI: 10.1016/j.foodchem.2014.12.098

[24] S. S. Choi and J. M. Regenstein, Physicochemical and sensory characteristics of fish gelatin. Journal of Food Science, 65(2) (2000) 194-199.

[25] F. Badii and N. K. Howell, Fish gelatin: structure, gelling properties and interaction with egg albumen proteins. Food hydrocolloids, 20(5) (2006) 630-640.

[26] B. Jamilah and K. G. Harvinder, Properties of gelatins from skins of fish-black tilapia (Oreochromis 
mossambicus) and red tilapia (Oreochromis nilotica). Food chemistry, 77(1) (2002) 81-84.

[27] GMIA. Gelatin Manufacturers Institute of America Gelatin Handbook. America: (2012) New York, NY, USA

[28] M. M. Mahyeddin, A. H. Mustafa'Afifi and A. M. Nazmi, An islamic view on the utilization of leeches and worms for pharmaceutical and cosmetic purposes. Middle East J. Sci. Res, 16 (2013) 17-21. doi:10.5829/idosi.mejsr.2013.16. s.100

[29] T. M. Hoesli and K. M. Smith, Effects of religious and personal beliefs on medication regimen design. Orthopedics, 34(4) 292-295. doi:10.3928/01477447- 20110228-17

[30] G. O. Phillips and P. A. Williams, Handbook of food proteins. Elsevier. 2011.

[31] G. Kavoosi, S. M. M. Dadfar, A. Mohammadi Purfard and R. Mehrabi, Antioxidant and antibacterial properties of gelatin films incorporated with carvacrol. Journal of Food Safety, 33(4) (2013) 423432.

[32] I. S. Arvanitoyannis, Formation and properties of collagen and gelatin films and coatings. Protein-based films and coatings, 467 (2002) 484.

[33] A. Widyaninggar, K. Triyana and A. Rohman (2012). Differentiation between porcine and bovine gelatin in capsule shells based on amino acid profiles and principal component analysis. Indonesian Journal of Pharmacy, 23 (2) (2012) 104-109

[34] M. A. Raraswati, K. Triyana and A. Rohman. Differentiation of bovine and porcine gelatins in soft candy based on amino acid profiles and chemometrics. Journal of Food and Pharmaceutical Sciences 2(1) (2013) 1-6.

[35] I. J. Haug, K. I. Draget and O. Smidsrød, Physical behaviour of fish gelatin- $\kappa$-carrageenan mixtures. Carbohydrate Polymers, 56(1) (2004) 11-19.

[36] N. F. Mohtar, C. O. Perera and S. Y. Quek, Utilisation of gelatine from NZ hoki (Macruronus novaezelandiae) fish skins. International Food Research Journal, 18(3) (2011).

[37] G. S. Al-Saidi, A. Al-Alawi, M. S. Rahman and N. Guizani, Fourier transform infrared (FTIR) spectroscopic study of extracted gelatin from shaari (Lithrinus microdon) skin: effects of extraction conditions. International Food Research Journal, 19(3) (2012) 1167
[38] F. Zhang, S. Xu and Z. Wang, Pre-treatment optimization and properties of gelatin from freshwater fish scales. Food and bioproducts processing, 89(3) (2011) 185-193.

[39] R. J. Avena-Bustillos, B. S. Chiou, C. W. Olsen, P. J. Bechtel, D. A. Olson and T. H. McHugh, Gelation, oxygen permeability, and mechanical properties of mammalian and fish gelatin films. Journal of food science, 76(7) (2011) E519-E524.

[40] T. Aewsiri, S. Benjakul, W. Visessanguan, J. B. Eun, P. A. Wierenga and H. Gruppen, Antioxidative activity and emulsifying properties of cuttlefish skin gelatin modified by oxidised phenolic compounds. Food Chemistry, 117(1) (2009) 160-168.

[41] S. K. Kim, H. G. Byun, P. J. Park and F. Shahidi, Angiotensin I converting enzyme inhibitory peptides purified from bovine skin gelatin hydrolysate. Journal of Agricultural and Food Chemistry, 49(6) (2001) 2992-2997.

[42] L. You, J. M. Regenstein and R. H. Liu, Optimization of hydrolysis conditions for the production of antioxidant peptides from fish gelatin using response surface methodology. Journal of food science, 75(6) (2010) C582-C587.

[43] D. H. Ngo, T. S. Vo, B. Ryu and S. K. Kim, Angiotensin-I-converting enzyme (ACE) inhibitory peptides from Pacific cod skin gelatin using ultrafiltration membranes. Process Biochemistry, 51(10) (2016) 1622-1628.

[44] M. Jridi, N. Souissi, A. Mbarek, G. Chadeyron, M. Kammoun and M. Nasri, Comparative study of physico-mechanical and antioxidant properties of edible gelatin films from the skin of cuttlefish. International journal of biological macromolecules, 61 (2013) 17-25.

[45] A. A. Karim and R. Bhat, Fish gelatin: properties, challenges, and prospects as an alternative to mammalian gelatins. Food hydrocolloids, 23(3) (2009) 563-576.

[46] A. Batu, J. M. Regenstein and I. S Dogan, I. S. (2015). Gelatin Issues in Halal Food Processing for Muslim Societies. Electronic Turkish Studies, 10(14) (2015).

[47] N. M. Nik Aisyah, H. Nurul, M. E. Azhar and Fazilah, A. Poultry as an alternative source of gelatin. Health and the Environment Journal 5(1) (2014) 37-49.

[48] A. Lasekan, A.F. Bakar, and D. Hashim, Potential of chicken by-products as sources of useful biological resources. Waste Management. 33 (2013) 552-565. 
[49] N. M. Sarbon, F. Badii and N. K. Howell, Preparation and characterisation of chicken skin gelatin as an alternative to mammalian gelatin. Food Hydrocolloids, 30(1) (2013) 143-151.

[50] W. H. W. Omar and N. M. Sarbon, Effect of drying method on functional properties and antioxidant activities of chicken skin gelatin hydrolysate. Journal of food science and technology, 53(11) (2016) 3928-3938.

[51] A. I. Saiga, K. Iwai, T. Hayakawa, Y. Takahata, S. Kitamura, T. Nishimura and F. Morimatsu, Angiotensin I-converting enzyme-inhibitory peptides obtained from chicken collagen hydrolysate. Journal of Agricultural and Food Chemistry, 56(20) (2008) 9586-9591.

[52] T. Nagai and N. Suzuki, Preparation and characterization of several fish bone collagens. Journal of Food Biochemistry, 24(5) (2000) 427-436.

[53] L. H. Pelizer, M. H. Pontieri and I. de Oliveira Moraes, Utilização de resíduos agro-industriais em processos biotecnológicos como perspectiva de redução do impacto ambiental. Journal of Technology Management \& Innovation, 2(1) (2007) 118-127.

[54] Z. U. L. A. L. Kesmen, F. Sahin and H. Yetim, PCR assay for the identification of animal species in cooked sausages. Meat science, 77(4) (2007) 649-653. DOI: $10.1016 /$ j.meatsci.2007.05.018

[55] P. K. Teng, W. J. W. Jusoh, H. K. Siong and M. M. Mesbahi, Awareness, recognition and intention: Insights from a non-Muslim consumer survey regarding halal labeled food products in Malaysia. In $3 r d$ International conference on management proceeding (2013) 10-11.

[56] R. Golnaz, M. Zainalabidin, S. Mad Nasir and F. C. Eddie Chiew, Non-Muslims' awareness of Halal principles and related food products in Malaysia. International food research journal, 17(3) (2010) 667-674

[57] A. Rohman, Y. Erwanto and Y. B. C. Man, Analysis of pork adulteration in beef meatball using Fourier transform infrared (FTIR) spectroscopy. Meat Science, 88(1) (2011) 91-95. DOI: 10.1016/j.meatsci.2010.12.007

[58] J. M. N. Marikkar, H. M. Ghazali, Y. C. Man, T. S. G. Peiris, and O. M. Lai, Distinguishing lard from other animal fats in admixtures of some vegetable oils using liquid chromatographic data coupled with multivariate data analysis. Food Chemistry, 91(1) (2005) 5-14.

[59] L. Necidova, E. Rencova and I. Svoboda, Counter immunoelectrophoresis: a simple method for the detection of species-specific muscle proteins in heat- processed products. VETERINARNI MEDICINAPRAHA-, 47(5) (2002) 143-147. DOI: 10.17221/5818VETMED

[60] Y. Erwanto, M. Z. Abidin and A. Rohman, PCRRFLP using BseDI enzyme for pork authentication in sausage and nugget products. Media Peternakan, 34(1) (2011) 14-14.

[61] S. Soares, J. S. Amaral, M. B. P. Oliveira and I. Mafra, A SYBR Green real-time PCR assay to detect and quantify pork meat in processed poultry meat products. Meat Science, 94(1) (2013) 115-120. DOI: 10.1016/j.meatsci.2012.12.012

[62] A. R. Alina, M. N. Illiyin, J. Juriani, Y. Salmah, A. S. Mashitoh and A. K. Imtinan, Detection of Non-Halal Plasma Transglutaminase in Selected Surimi-Based Products by using Sandwich ELISA Method. World Applied Sciences Journal, 17 (2012) 39-44.

[63] Y. Erwanto, R. Yuliatmo, S. Sugiyono, A. Rohman and S. Sismindari, Species specific polymerase chain reaction (PCR) assay for identification of pig (Sus domesticus) skin in "Rambak" crackers. 2016.

[64] A. M. Sahilah, M. L. Fadly, A. S. Norrakiah, A Aminah, W. W. Aida, A. G. Ma'aruf and M. A. Khan, Halal market surveillance of soft and hard gel capsules in pharmaceutical products using PCR and southernhybridization on the biochip analysis. International Food Research Journal, 19(1) (2012) 371.

[65] S. Abd Mutalib, N. M. Muin, A. Abdullah, O. Hassan, W. A. W. Mustapha, N. A. Sani and M. Y. Maskat, Sensitivity of polymerase chain reaction (PCR)-southern hybridization and conventional PCR analysis for Halal authentication of gelatin capsules. LWT-Food Science and Technology, 63(1) (2015) 714-719.

[66] M. N. Riaz and M. M. Chaudry, Halal food production. CRC press. 2003.

[67] J. A. N. Shaari and N. S. Mohd Arifin, Dimension of halal purchase intention: A preliminary study. 2009.

[68] N. A. Ahmad, T. N. Abaidah and M. H. A. Yahya, A study on halal food awareness among Muslim customers in Klang Valley. In The 4th International Conference on Business and Economic Research (4th icber 2013) Proceeding 1074.

[69] D. K. Windisukma and I. Widiyanto, Pengaruh kesadaran halal terhadap sikap dan implikasinya terhadap minat beli ulang (Doctoral dissertation, Fakultas Ekonomika dan Bisnis). 2015.

[70] N. Yunus, W. Rashid, N. Ariffin, and N. Rashid, 'Muslim's purchase intention towards non-Muslim's 
Halal packaged food manufacturer', in 4th International Conference on Marketing and Retailing 2013, INCOMaR 2013, Elsevier, (2013) 145-154,

[71] A. M. Bashir, A. Bayat, S. O. Olutuase and Z. A. Abdul Latiff, Factors affecting consumers' intention towards purchasing halal food in South Africa: a structural equation modelling. Journal of Food Products Marketing, 25(1) (2019) 26-48.

[72] M. Machali, A. Rose, \& L.A. Razak, The Effect of Halal Awareness on Purchase Decision with Religiosity as A Moderating Variable: A Study at Higher Education Institutions in Brunei Darussalam. (2013). 